Acta vet. scand. 1961, 2, 178-184.

From 1. Department of Microbiology, School of Public Health, Harvard University, Boston, Massachusetts.

2. Department of Health, Education, and Welfare, Public Health Service, National Institutes of Health, National Institute of Allergy and Infectious Diseases, Rocky Mountain Laboratory, Hamilton, Montana.

3. Statens Veterinärmedicinska Anstalt, Stockholm, Sweden.

\title{
ADIASPIROMYCOSIS (HAPLOMYCOSIS) IN SWEDEN
}

\author{
By \\ William L. Jellison (1, 2), J. William Vinson (1), \\ and Karl Borg (3).
}

Haplomycosis was the name applied to infection in animals by a pulmonary fungus. This fungus was first described as Haplosporangium parvum by Emmons and Ashburn (1942). Recently the generic name of the organism has been changed to Emmonsia by Ciferri and Montemartini (1959) and a new species, Emmonsia crescens, has been described by Emmons and Jellison (1960). Emmons and Jellison (1960) have also proposed the name adiaspiromycosis for infections with these organisms.

In 1956, adiaspiromycosis (= haplomycosis) was reported in a Swedish rodent (Jellison, 1956). This report was based on the finding of 2 tissue spherules, $203 \mu$ in diameter, in the lungs of a wood mouse, Apodemus flavicollis, collected near Gullgruva, Gävleborg County, Sweden. The specimens of lungs were preserved in alcohol and shipped to the United States for examination so culture of this specimen was not possible.

It seemed highly desirable to verify this interesting finding by actual culture of the organism because it was the first recognition of the fungus from continental Europe, although McDiarmid and Austwick (1954) had already found it in England. They found a number of moles, Talpa europaea, infected and definitely identified the fungus by culture of the mycelial phase.

A further search for adiaspiromycosis in Sweden was made in April 1959. Many specimens of wild animals sent to the State 
Veterinary Medical Institute for routine autopsy were examined for Emmonsia. A trap line for small mammals was set out in the small section of forest within the Institute grounds and this yielded a number of animals for examination. Small mammals preserved in alcohol or formalin at the Swedish Museum of Natural History were examined through the courtesy of Mr. $U$. Bergström, Curator.

In the course of these studies from April 15 to April 28, 1959, 158 animals were examined (Table I). Four of these animals

Table I.

Animals Examined for Adiaspiromycosis in Sweden, April 1959.

\begin{tabular}{lrrrr}
\hline & $\begin{array}{c}\text { Fresh } \\
\text { Specimens }\end{array}$ & $\begin{array}{c}\text { Museum } \\
\text { Specimens }\end{array}$ & Total & $\begin{array}{c}\text { No. } \\
\text { Infected }\end{array}$ \\
\hline House mice, Mus musculus & 35 & 0 & 35 & 0 \\
Wood mice, Apod emus spp. & 29 & 0 & 29 & 2 \\
Shrews, Sorex sp. & 22 & 0 & 22 & 0 \\
Red-backed mice, Clethrionom y & 4 & 16 & 20 & 0 \\
Lemming, Lem mus sp. & 0 & 17 & 17 & 0 \\
Voles, Microtus & 6 & 5 & 11 & 1 (Museum) \\
Mink, Mustela vison & 7 & 0 & 7 & 0 \\
Hares, Lepus sp. & 5 & 0 & 5 & 0 \\
Rats, Rattus norvegicus & 3 & 2 & 5 & 0 \\
Shrews, probably water shrews, & & & & \\
$\quad$ Neomys fodiens & 1 & 3 & 4 & 1 (Museum) \\
Pine marten, Martes & 1 & 0 & 1 & 0 \\
Fox, Vulpes sp. & 1 & 0 & 1 & 0 \\
Nutria, Myocastor coypus (an & & & & \\
$\quad$ exotic rodent) & 1 & 0 & 1 & 0 \\
\hline Total & 115 & 43 & 158 & 4 \\
\hline
\end{tabular}

were found to have adiaspiromycosis. Cultures were established from two freshly trapped rodents and representative cultures have been identified as Emmonsia crescens by Dr. Chester W. Emmons, National Institutes of Health, Bethesda, Maryland, U.S.A. The type specimen of E. crescens came from Arvicola terrestris at Hamar, Norway.

Although most of the animals came from the vicinity of Stockholm, a few were from other areas. Four red-backed mice, Clethrionomys sp., came from Luleå, Sweden, April 1959. The samples of microtine rodents, Microtus, Clethrionomys, and Lemmus, 48 in all, were entirely inadequate for this type of 
study. It would be very desirable to examine a larger number of these and also specimens of Arvicola and Ondatra from central and northern Sweden for the presence of this parasite.

The data concerning the 4 infected animals are as follows:

No. 262, Apodemus $q$, trapped on Veterinary Institute grounds, April 19-20, 1959. One spherule in lung, culture established.

No. 274, Apodemus, trapped on Veterinary Institute grounds, April 21, 1959. Many spherules in lungs. Cultures established. Measurement of 8 spherules: $237 \mu$ minimum, $370 \mu$ maximum, $271 \mu$. average (Figure 1).

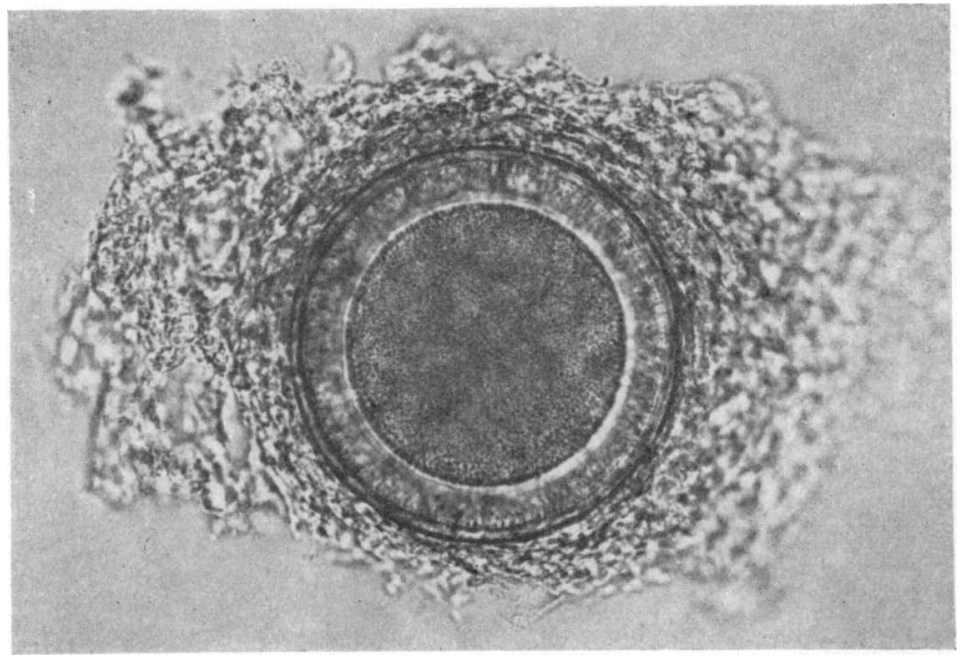

F i g. 1. Spherule from Apodemus sp., Stockholm, Sweden, April 21, 1959, optical section, about $270 \mu$ idameter, magnification about $136 \times$. Photo by N. J. Kramis.

No. 340, Microtus agrestis, museum specimen preserved in Swedish Museum of Natural History, collected at Lund, 1845, by $M$. V. Düben. One spherule in lungs. Spherule mounted on microslide and measured $414 \mu$ diameter (Figure 2).

This is the earliest known collection record of Emmonsia.

No. 350, shrew, probably a water shrew, Neomys fodiens, one of three large shrews preserved in a jar at Swedish Museum of Natural History. Collected 1908 at Engelsberg, Province of Västmanland, west of Stockholm. At least 11 spherules in lungs. Measurements of 5 spherules: minimum $355 \mu$ maximum $400 \mu$, average $377 \mu$.

None of the infected animals showed macroscopic evidence of disease. 


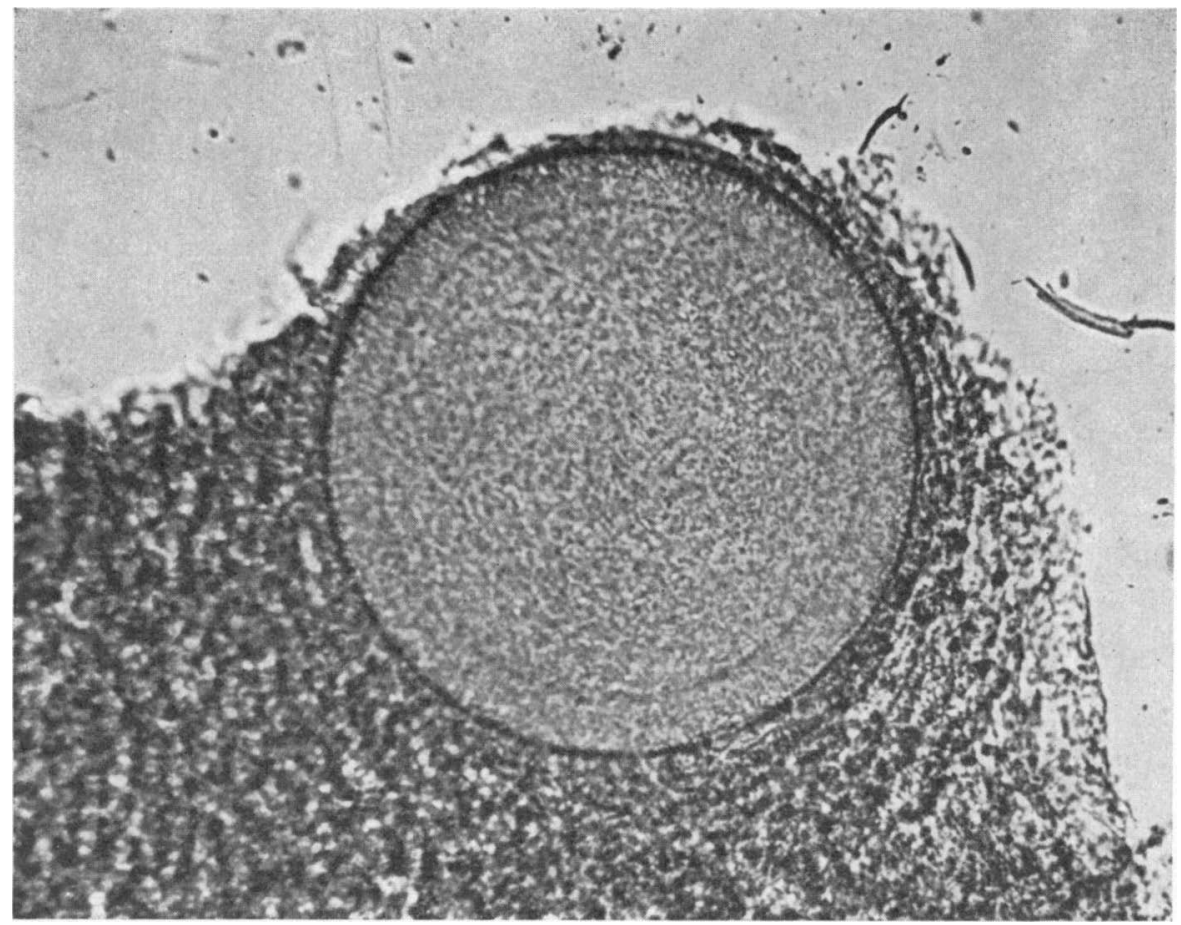

Fig. 2. Spherule from Microtus agrestis preserved in Swedish Museum of Natural History, collected Lund, Sweden, 1845 by $M$. V. Düben. Optical section. $414 \mu$ diameter. Magnification about $136 \times$. (This is earliest known collection record of Emmonsia.) Photo by N. J. Kramis.

0 865/60. During February 1960, an otter (Lutra lutra) was found dead in the vicinity of Rättvik, Kopparberg County of Sweden. The animal was sent to the State Veterinary Medical Institute in Stockholm for examination where the following was stated.

The animal was a male otter with a body weight of $2.2 \mathrm{~kg}$. (about 5 pounds). It was completely emaciated. The main macroscopic autopsy findings were abundant small nodules scattered all over the lung tissue. The nodules were yellowish and firm and about the size of a pin's head. Microscopically, a great many spherules of $E$. crescens were found in the lung tissue. The spherules measured $250-300 \mu$ in diameter and had a thick strongly PAS-positive capsule. Around these spherules there were lymphohistiocytic cells as well as some plasma cells, epitheloid 


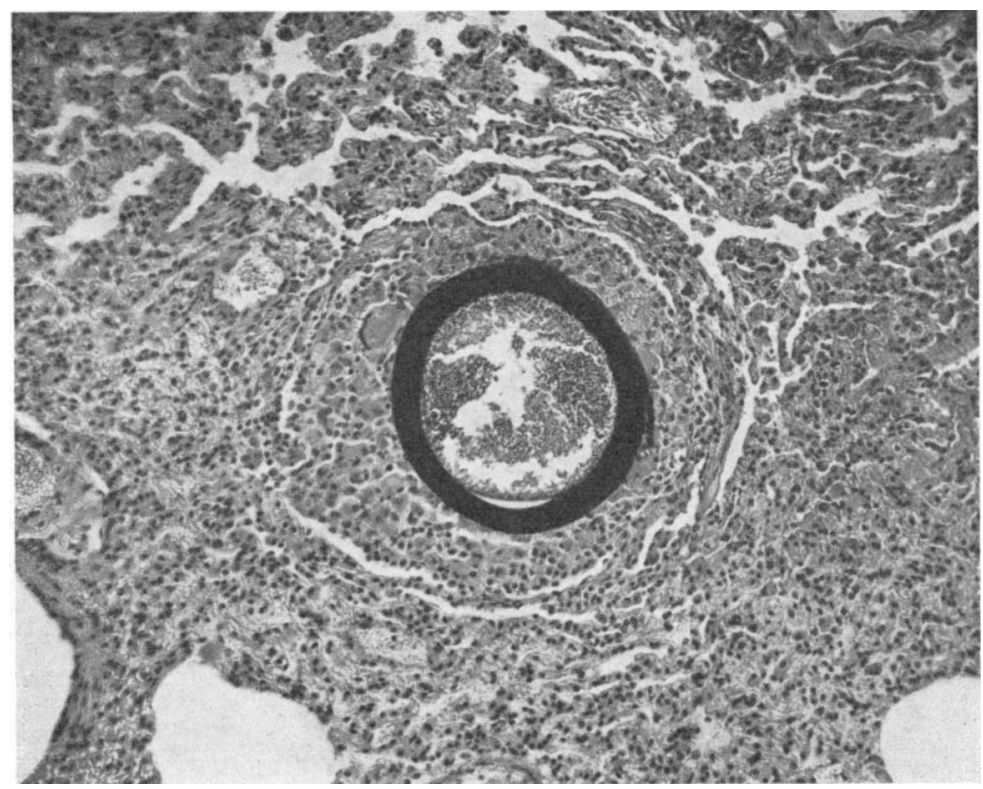

Fi g. 3. Spherule in lung tissue from Lutra lutra, Sweden, February 1960. Histological section $136 \times$. Photo by N. J. Kramis.

cells, and multinuclear giant cells (Figures 3 and 4 ). Thus, the lungs were the seat of a great many granulomatous foci, which sometimes joined to form larger areas of a chronic pneumonia. Liver, kidney, heart, and spleen did not show any significant changes. The cause of death was apparently emaciation which in its turn must be largely ascribed to the chronic granulomatous lesions of the lungs caused by the spherules. Bacteriological and parasitological examination of the case gave negative result. The diagnosis of Emmonsia has been done only by means of morphological criteria. The spherules were detected after the material had been processed for histology which unfortunately was too late for culturing the organism.

A great variety of wild animals have been found to harbour Emmonsia and in some instances the spherules have been extremely abundant yet the hosts appeared to be healthy. Massive experimental infections, however, are fatal to laboratory animals. In the present material, the infection of the otter also seemed to have been fatal to the animal. The host tissue showed a definite reaction in the form of a severe granulomatous inflammation and the animal was emaciated. 


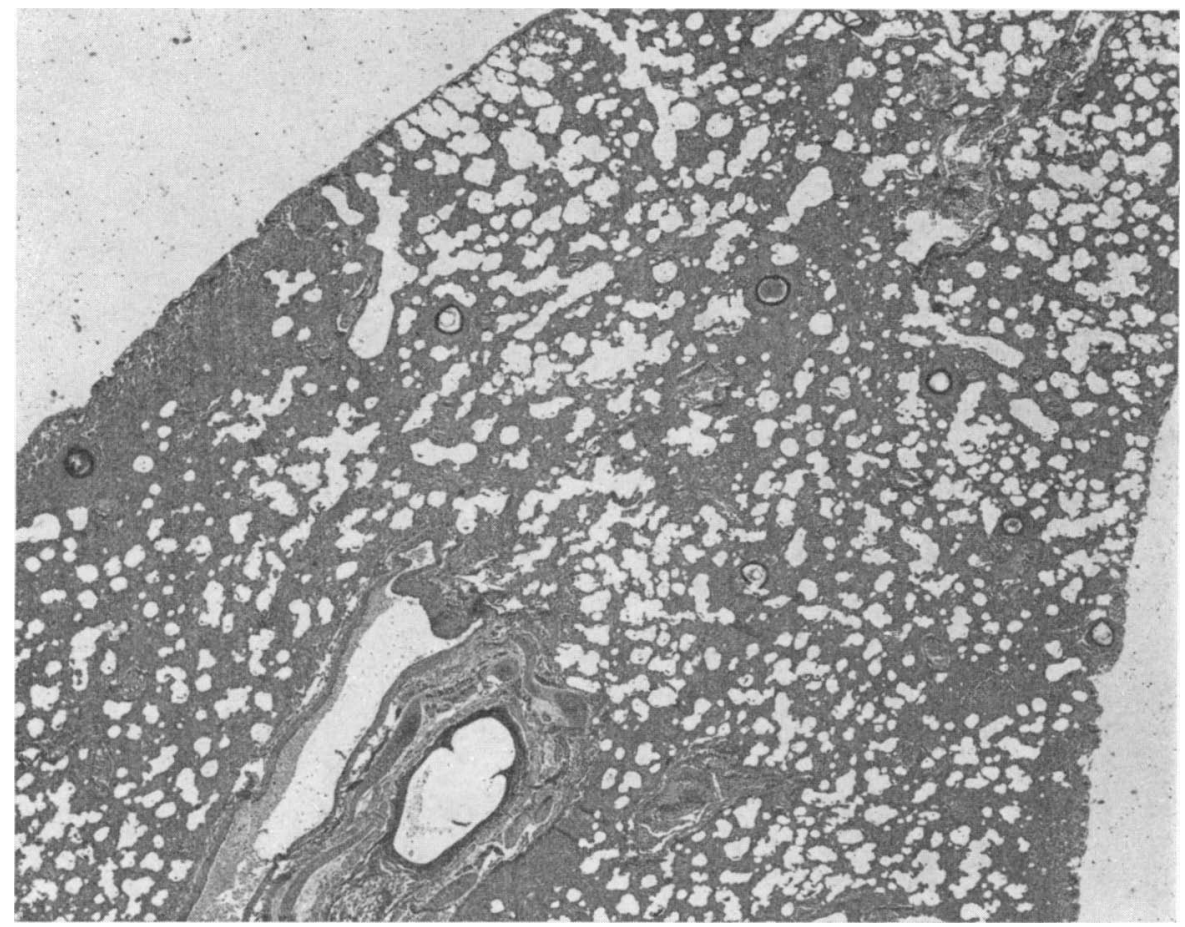

Fig. 4. Section of lung from Lutra lutra, Sweden, February 1960. $15 \times$. Photo by N. J. Kramis.

It seems also natural to ask whether Emmonsia might be associated with some disease in domestic animals or man. Jellison et al. (1960) have suggested that there might be an association between Emmonsia in rodents and "nephropathia epidemica" in man. This disease has been diagnosed in Sweden as well as in the neighboring countries (Myhrman 1951, Hortling 1946, Knutrud 1949, and Muri 1950). These authors and other clinicians familiar with the disease have postulated that rodents are the source of infection, assuming that an infectious agent is involved. The findings of Emmonsia in Sweden have occurred in endemic areas of "nephropathia epidemica" as well as in other areas, thus offering no answer to the question whether there is a relationship or not between these two phenomenon. Thus the question remains open as far as the conditions in Sweden are concerned. 


\section{REFERENCES}

Emmons, C. W. and Ashburn, L. L.: Public Health Reports 1942, 57, 1715.

Hortling, H.: Nord. Med. 1946, 30, 1001.

Knutrud, O.: Tidsskr. Norske Lægeforen. 1949, 11, 259.

Muri, A. J.: Nord. Med. 1950, 43, 290.

Myhrman, G.: Acta med. scand. 1951, 140, 1.

McDiarmid, A. and Austwick, P. K. C.: Nature 1954, 174, 843.

Jellison, W. L.: Nord. Vet.-Med. 1956, 8, 504.

Ciferri, R. and Montemartini, A.: Mycopath. Mycolog. applicat. 1959, $10,303$.

Jellison, W. L., Vinson, J. W. and Holager, E.: Acta path. microbiol. scand. 1960, 49, 480.

Emmons, C. W. and Jellison, W. L.: Ann. N. Y. Acad. Sci. 1960, 89, 91.

\section{SUMMARY}

The authors report five additional cases of adiaspiromycosis among wild animals in Sweden. In an otter, Lutra lutra, the organism had produced severe pulmonary lesions: and this infection was considered the cause of emaciation and death.

\section{ZUSAMMENFASSUNG}

Adiaspiromycosis (Haplomycosis) in Schweden.

Die Verfasser berichten über fünf neue Fälle von Adiaspiromycosis unter wilden Tieren in Schweden. Bei einem Fischotter, Lutra lutra, hatte dieser Organismus schwere Schäden in den Lungen hervorgerufen, und es wird angenommen, dass diese Infektion die Abmagerung und den Tod verursacht hatte.

\section{SAMMANFATTNING}

Adiaspiromykos (haplomykos) i Sverige.

Förff. rapportera ytterligare 5 fall av adiaspiromykos bland vilda djur i Sverige. I ett av fallen, en utter, Lutra lutra, hade svampen åstadkommit en svårartad lunginflammation. Infektionen uppfattas i detta fall som orsak till djurets utmärgling och död. 